\title{
Getting Experience through Experiments and Practice: Learning to Translate Ancient Chinese Poetry
}

\author{
Huifang Tian \\ School of Foreign Languages, China University of Petroleum, Beijing, China
}

\begin{abstract}
The translation of ancient Chinese poetry (TACP) is one important aspect of literature translation, and perhaps even more difficult than the translation of English poetry into Chinese. The difficulty is partly attributed to the gap between the learning of E-C translation and its counterpart, the former still facilitating language acquisition while the latter moving away from it, and partly to the lacking of workable learning activities of TACP in the classroom. This study sheds light on TACP in the classroom in the L2context. It examines various procedures leading to the realization of learners' way to TACP, and suggests that average language teachers with a mind to the genre are capable of devising similar activities as discussed in the thesis. The purpose of this study is to promote TACP from the classroom setting, with average college learners as the subject, and to promote literature translation on a grassroot basis. The study draws on the argument that language learning and motivating materials are mutually promoting and on common-sense view that practice makes perfect. The design of the procedures and activities are based on the previous teaching experience gained from a literature translation course. Given that both the students and the teachers involved in TACP are learners, the success of the classroom interaction to tackle the ancient poetry lies in the specific steps of work, the low-level challenge of the activities and the interest and enthusiasm put in by the students and the teacher.
\end{abstract}

Index Terms - learning, translation, ancient poetry

\section{INTRODUCTION}

In China literature study is either an elective or a compulsive course for most English-major students of tertiary education. For English-major and science students alike literature-related material is used in reading course books or translation text-books. Extracts of short stories or novels usually appeal to L2 learners, as well as to language teachers, who are able to make use of its rich contents to design motivating activities. Kurn (2009) sees the educational value of literature in that reading literature develops skills that involve the abilities for discrimination, judgment, and decision. In this electronic age people feel a need to absorb information from conventional and digital sources and channels, as well a need to disseminate information, knowledge about a culture, history, literature, etc. Online pop literature is all around us, most of the authors being grassroots non-professionals. Anyone with secondary education may be a media audience or even a micro-media unit, absorbing or/and reporting life stories in semi-literature and semi-journalistic forms. In fact there is no clear division between literary and non-literary language, and that literature has no obvious and clear language of its own (Hall: 2005). In the context of globalization, literature translation in general, and poetry translation in particular, are gaining momentum in bridging different cultures and gaps of understanding.

Translation of classical Chinese poetry used to be job of the few highbrows, the specialists in both languages and in both poetry, and the studies of such topics are largely centered on aesthetic aspects of the genre, reviewing and appreciating the masters' translations (Tian 2013). In recent years, especially with the popularity of the Internet amateurs begin to take a keen interest in the classical poetry translation. translators.com.cn introduces creative work and translated products of both professionals and lovers of poetry translation. blog.163.com publishes amateurs' translation of the ancient poetry, together with their own writing and translation work. But altogether C-E translation is not as flourishing as E-C translation, and the translation of the Western poetry fares much better than its counterpart that of the Chinese poetry, particularly of ancient Chinese poetry. The difficulty involved in the latter is of two facets, comprehending the original poem and putting it into a piece with similar poetic sound and stylistic pattern. This is never easy for translating the ancient Chinese poems, most of which are written hundreds of years ago, containing old-style phrases new to the modern readers. To most of the language learners, translation probably starts with Chinese itself: turning the archaic expressions into the modern popular ones. The tasks that follow entail lots of hard work done in comparative linguistics, in rewriting and paraphrasing (Lefevere, 2011). This practice may benefit advanced learners, when productive skill becomes their focus, and they are required to write their own research thesis and want to express their literary taste.

To involve more learners in observing models and accomplishing tasks, and to ensure a rewarding learning experience, it is obvious and necessary to treat the matter systematic, to consider it as a curriculum, on one-semester 
basis, to furnish workable and variable activities, check progress and pool feedback. The word "learning" on the title is used rather than "teaching" because both the teacher and his/her students are learners, besides the masters of translation. The components of such an ancient poetry translation course would include the initial comprehension in the two languages, teacher-guided translation activities, and contextualized reading of poetic features or translation theory/techniques. Such a curriculum aims at a balance between the product and process of translation.

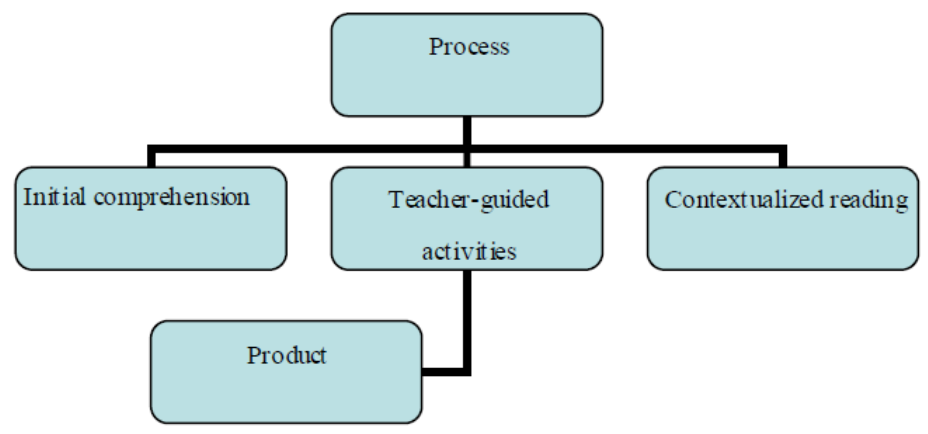

This diagram shows that the process is as important as the product, which is the outcome of systematic learning, and this is especially true of the ancient Chinese poetry translation. The classroom training of translators is like the training of novelists, poets, giving the trainees enough experience for observing the masterpieces and getting done workable activities.

\section{TheOreticAl BACKGROUND}

\section{A. Making It Amateurs' World As Well}

Literature translation is going to be undertaken by amateurs and non-professionals as well as by the professional practitioners as a result of information boom on the internet. As afro-mentioned, literature lovers not just write their own stories and poetry, but have blogs to share their translations with other net users. Littlewood (2006) believes that the world created by literature is a foreign one, and thus is a way of assimilating knowledge of this foreign world. And why do we do literary translation? There are other purposes of translation, of science, finance, advertising for instance, but only literary translation enables the translator to share with the author the process of creation (Landers 2008).

\section{B. Process and Product}

Translation is a process, involving the coordination between the text producer and receiver (Hatim \& Mason, 2005). The English translation of ancient poetry used to be product-oriented, so that only the real craftsmen know the skill, which is hard to be imparted to general learners. In the recent decades translation theorists have begun to view it as a linguistic process, able to be developed from structural, syntactic and semantic units. Huang (2006) attempts to analyze the procedures from empirical, interpersonal and logical perspectives. He discusses specific matters such as the persons and pronouns in analyzing the original poem. It is generally believed that translation means interpretation and that the translator is the mediator of the two texts, not the finder of equivalence, and that a translator produces communicative translation rather than a semantic one. Quah (2008) uses a three-word term: product, function and process, arguing that technology is most possible to be applied to product and process. In the case of the average learners attempting to do TACP, process is as important as product, which is a productive skill to emerge with enough target language experience.

\section{Previous Findings on the TACP}

In the recent decades, translation practitioners and theorists have come up with practical ideas and concepts that back up these ideas. Zhang (2002) argues that in TACP translators need to take care of both the meaning and form of the original poems and reflect them in the translation. He suggests that the integrity means faithfulness to the source poems in every aspect. Some translation practitioners offer practical ideas and techniques in their practice. The guide provides reference for theoretical studies and workable practice, is a valuable book for learners and teachers of a given translation course. Zhuo (2011) wrote a book called A Theoretical Outline of Chinese Verse Translation, which deals such matters as the quality of classic literature translation, criteria of English translation of Chinese poetry, comparative studies of Chinese poetry in English translation. These topics will prove useful in a TCCP curriculum. Also significant the established and budding C-E translators of classic works, in which beautiful translations are produced, poets' backgrounds provided, and sometimes the translation process discussed. Xu (2010) in one of his many masterpieces produced first-class translations as well as notes to the poets, and comparable English poetry. His translations and descriptions will provide excellent learning materials.

\section{RATIONALE AND RESEARCH QUESTION}

The focus of this empirical study is tertiary learners through teacher guidance and models to eventually acquire some 
basic skills of TACP. The study assumes that a curriculum of that status embraces procedures in teaching as well as learning, in development and consolidation of productive and receptive skills. This particular competence depends on the overall language proficiency, but the general awareness acquired in the classroom will serve to add to their enthusiasm about this genre, and to promote their amateur or professional pursuit. Unlike E-C poetry translation, where the final product is in the home language, which is relatively strong, C-E poetry translation requires a strong basis of target language, which is nonetheless lacking for most Chinese student translators. On the other hand, anyone who attempts the project is in a position to learn a language in a comparative way, to learn diligently and make breakthroughs. That's precisely the point for a curriculum in the making, to give learners tasks which suit their level, and which are easy to handle and use, and eventually make it possible to learn poetry translation in the classroom. Furthermore, the trend of globalization has set the cultural exchange in motion, and translation become a window for ordinary people to understand a culture, and the ancient poetry translation practice benefits the learner translators, but also those who are keen on Chinese and its culture, particular its culture in a literary fashion. In this investigative research, the following research question will be addressed:

How would a well-developed curriculum facilitate classroom practice and encourage learn translator of the ancient poetry?

Predictably the answer should be a positive one, based on my teaching experience. The course, if anything, is usually meant for learners of science and technology, as well as for English-major learners. The classroom interaction is not just concerned with translation theories or aesthetic appreciation, not with the skill development itself. The curriculum on which this paper elaborates is practice-oriented, concerned with actual development of the translation skills and technique.

\section{METHOD}

This empirical study is based on the author's teaching experience with one class of 30 university students, taking a literature translation course, part of which is the classic poetry translation. They are inexperienced in this area of learning, but the topic is not entirely new to them; all of them have had some experience of reading old-style of Chinese and the ancient poetry. They are not skillful; nevertheless, they are enthusiastic about the class activities. The method, then, refer to follow-up summary and the experiment to design a trio-aspect activities suit learning to TACP.

\section{A. Description of the Literature Translation Course}

This is a one-semester elective course for tertiary college L2 learners, containing literature appreciation and the development of C-E translation skill. The course consists of literary reading in Chinese and English and TACP activities. The purpose of the course is to raise awareness of reading Chinese literature in a comparative context and develop competence in C-E translation, which is a particular weak area of the skills. In learning English in China there has been a delay of this skill, which attributes to two reasons, one being the fear that the mother tongue will interfere with the language acquisition, the other de-contextualization, meaning $\mathrm{C}-\mathrm{E}$ translation is less effective than E-C translation, for lacking target language reference.

With the combined enthusiasm and efforts TACP appears to have achieved a moderate success. The learners are motivated by the genre and enthusiastic about the activities. Feedback is conducted through a question-sheet, with general and specific questions to elicit the learners' opinions, comments and suggestions. In addition, the end-term test questions are designed in such ways as to show much of the learners' awareness about such matters as sentence rhyming, structure balance, brevity and terseness, as their actual capability of translating lines or phrases.

TABLE 1

SAMPLE OF QUESTION SHEET.

\begin{tabular}{|l|l|l|l|}
\hline \multicolumn{3}{|c|}{ How do you like the course? } & SAMPLE OF QUESTION SHEET. \\
\hline $\begin{array}{l}\text { Your name } \\
\text { (optional) }\end{array}$ & $\begin{array}{l}\text { A. I I like it much. } \\
\text { B. It's just OK. }\end{array}$ \\
\hline & $\begin{array}{l}\text { C. I don't like it very much. } \\
\text { D. I have no opinion. }\end{array}$ & \\
\hline
\end{tabular}


TABLE 2

\begin{tabular}{|c|c|}
\hline General knowledge & SUMMARY OF TEST QUESTIONS \\
\hline $\begin{array}{l}\text { What rhetorical feature is found in the following lines } \\
\text { of translation from a poem written by Li Bai? a) } \\
\text { alliteration } \\
\text { b) assonance }\end{array}$ & $\begin{array}{l}\text { 床前明月光, 疑是地上霜。 } \\
\text { Before my bed shine bright the silver beams, } \\
\text { It seems the autumn frost on the ground so gleams. }\end{array}$ \\
\hline $\begin{array}{l}\text { What are the structures of the following two lines } \\
\text { from a poem written by Zhang Ji? } \\
\text { a) line 1: two clauses forming a compound sentence } \\
\text { line 2: adverbial and clause } \\
\text { b) line 1: two adverbials line } 2 \text { : subject and } \\
\text { predicate }\end{array}$ & $\frac{\text { 月落乌啼 }}{1} \frac{\text { 霜满天，江枫渔火 }}{2} \frac{\text { 对愁眠。 }}{2}$ \\
\hline Translation practice & \\
\hline $\begin{array}{l}\text { Match the word at the end of each line with one of the } \\
\text { same vowel sound in the translation. }\end{array}$ & $\begin{array}{l}\text { 月落乌啼 霜满天, 江枫渔火 对愁眠。 } \\
\text { Moon’s down, crows _ , and frosts fill all the sky. } \\
\text { By maples and boat__ I sleepless lie. }\end{array}$ \\
\hline $\begin{array}{l}\text { Choose one of the translations, from lines of a poem } \\
\text { written by Li Bai, and explain your reason for the } \\
\text { choice. }\end{array}$ & $\begin{array}{l}\text { 故人西辞黄鹤楼, 烟花三月下扬州。 } \\
1^{\text {st }} \text { version of translation: } \\
\text { You have left me behind, old friend, at the Yellow Crane Terrace, On } \\
\text { your way to visit Yangzhou in the misty month of flowers } \\
2^{\text {nd }} \text { version of translation: } \\
\text { From West Crane Tower my friend is on his way, } \\
\text { Down to Yangzhou in misty, flowery May. } \\
X u \text { Yuanchong's translation: } \\
\text { My friend has left the west where they Yellow Crane towers } \\
\text { For river Town veiled in green willows and red flowers. }\end{array}$ \\
\hline
\end{tabular}

\section{Summary of the replies and comments based on question-sheet and the test questions.}

Most learners have given positive feedback and expressed their enthusiasm about the learning literature and literature translation. Some feel poetry translation is entirely new to them, and a very demanding job, of which they are not quite capable of. Some enjoy working with partners and on the activities which are not very challenging. Some, however, feel frustrated for not being able to do as well as the established translators. Most of them agree that they need to work more systematically on such matters as rhyming, couplets, antithesis, alliteration, assonance, etc. Furthermore they need to compare language structures of the two languages. More importantly, they need techniques and guidelines to turn the phrases into similar ones with matching image, sound and sense. Some feel they have lost touch with the target language and are doing work which does them no avail in developing the foreign language.

\section{B. Adapted Components of a TACP Course}

This adaptation is based on the assumption that the content of the course is entirely TACP lasting one semester. In addition to the original two components, i.e. activities of translation on fragments of a poem, structural features of poetry, readings on translation theories, approaches, techniques and the western poetry are an added component, meant to balance up the lacking in contextualized language reference.

\section{GUIDING TO LEARN}

This chapter shows detailed class procedures in which the lecturer experiments using workable and not very challenging activities to guide them into TACP world. They are also trained to be conscientious learners with some awareness of theories, trends and approaches.

A. Description of the Components

As was mentioned in the previous chapter, the course is both product and process oriented, getting the learners to develop an awareness of the basic requirements of TACP, of the basic features of Chinese and English poetry, and theoretical and practical knowledge relevant to the skill development.

\section{Class activities}

Class activities consist of three procedures/phases: explanations on a poem, modeling and practice. The teacher's explanation is the beginning of the learners' comprehension of the poem, with notes given in both languages. Models that follow give ideas for interpreting the poem lines, alternative expressions or phrasing. Fragment translation invites the learners to work on one line or two, possibly based on specific techniques. 
TABLE 3

PHASE OF COMPREHENSION

\begin{tabular}{|l|l|l|l|}
\hline procedures & presentation & \multicolumn{2}{|c|}{ PHASE OF COMPREHENSION } \\
\hline 1. & The original poem & $\begin{array}{l}\text { e.g. reading out a poem by Wang } \\
\text { Changling, and giving the gist }\end{array}$ & $\begin{array}{l}\text { 秦时明月汉时关, 万里长征人未还。但使龙 } \\
\text { 城飞将在, 不叫胡马度阴山。 }\end{array}$ \\
\hline 2. & notes & e.g. allusion & $\begin{array}{l}\text { 龙城飞将: 龙城, probably a pass in Xifengkou, } \\
\text { in Lulong County of Hebei Province. 飞将, Li } \\
\text { Guang, an army general of Han dynasty. The } \\
\text { whole phrase means the heroic general } \\
\text { successfully guarding the national territory }\end{array}$ \\
\hline 3. & Discussion questions & $\begin{array}{l}\text { e.g. the meaning or implication of } \\
\text { certain word combinations }\end{array}$ & $\begin{array}{l}\text { Does “万里长征” refer to the distance between } \\
\text { Changan and the frontier? }\end{array}$ \\
\hline
\end{tabular}

\section{Summary}

Table 3 shows the first phase of class activities, i.e. the initial comprehension of a particular poem, which is done in two ways: in Chinese and English. As well as the notes containing terminology in Chinese and explanation in English, the teacher also explains the poem either in English or in Chinese, orally or in written notes, depending on the smoothness of comprehension. Notes are probably essential when archaic expressions have to be dealt with. Writings very remote in time require preliminary comprehension in Chinese (translation into modern Chinese before into a foreign language, if necessary). At this point discussions are conducted to help learners with interpretation.

TABLE 4

PHASE OF MODELING (BASED ON THE SAME POEM DISCUSSED ABOVE)

\begin{tabular}{|c|c|c|c|}
\hline $\begin{array}{l}\text { Modeling } \\
\text { items }\end{array}$ & & & \\
\hline 1. & $\begin{array}{l}\text { How to echo the } \\
\text { original phrase? }\end{array}$ & $\begin{array}{l}\text { by maintaining the original } \\
\text { structure and syntax or } \\
\text { adapting it? Make a choice. }\end{array}$ & $\begin{array}{l}\text { a) maintaining: } \\
\text { Qin's bright moon and Han's pass, neither } \\
\text { much change. } \\
\text { b) adaptation: } \\
\text { The moon shines as in Qin and the pass stands as } \\
\text { in Han }\end{array}$ \\
\hline 2. & $\begin{array}{l}\text { Reproducing the } \\
\text { original image }\end{array}$ & by maintaining or adaptation? & $\begin{array}{l}\text { a) maintaining: } \\
\text { army men marching thousands of miles to guard } \\
\text { b) adaptation: } \\
\text { guardsmen of the Great Wall }\end{array}$ \\
\hline 3. & $\begin{array}{l}\text { Considering rhyming } \\
\text { schemes }\end{array}$ & e.g. following abab or aabb? & $\begin{array}{l}\text { a) abab: } \\
\text { not much change/are no more/guard the land and } \\
\text { mount-range/approach our nation's door } \\
\text { b) aabb: } \\
\text { stands as in } \mathrm{Han} / \text { is our } \mathrm{man} / \mathrm{still} \text { there/not dare }\end{array}$ \\
\hline 4. & $\begin{array}{l}\text { Matching the original } \\
\text { couplets }\end{array}$ & $\begin{array}{l}\text { By using parallelism or } \\
\text { expressions in contrast? Make } \\
\text { a choice. }\end{array}$ & $\begin{array}{l}\text { a) The more frontiersmen heroically guard, the } \\
\text { fewer Nomads dare to pass (contrast) } \\
\text { b) We miss heroic General Li who gave our land } \\
\text { peace, the Nomadic horse hoofs to annoy us } \\
\text { cease (parallelism) }\end{array}$ \\
\hline 5. & Considering the meter & $\begin{array}{l}\text { e.g. revising translated lines } \\
\text { by providing the same } \\
\text { number of stressed syllables }\end{array}$ & $\begin{array}{l}\text { The `moon `shines as'n `Qin and the `pass } \\
\text { 'stands as'n `Han (6 stressed syllables) } \\
\text { The original: } \\
\text { Our `guardsmen to `frontiers `far `went, `never } \\
\text { `returned `protecting this `land ( } 8 \text { stressed } \\
\text { syllables) } \\
\text { Revision: } \\
\text { 'Long `marched our `guardsmen, who `died } \\
\text { 'protecting this `land (6 stressed syllables) }\end{array}$ \\
\hline 6. & $\begin{array}{l}\text { Observing other } \\
\text { rhyming techniques in } \\
\text { the masters' translation }\end{array}$ & e.g. alliteration, assonance & $\begin{array}{l}\text { alliteration: } \\
\text { moon/mountain; still/shine } \\
\text { assonance: } \\
\text { guardsman/passes/command }\end{array}$ \\
\hline
\end{tabular}

\section{Summary}

Table 4 gives a glimpse of aspects of TACP within the reach of the learners. There could be more of such exercises as long as they serve to build their interest and improve their translation skills. Admittedly the exercises are meant to impart the teacher's limited knowledge and masters' techniques to the learners, in what appears acceptable ways. There are two models in each exercise, for both comparison and choice, on the basis of which practice is to happen. The two-facet models also indicate there are two comparable translations instead of the only one, although none of them read as smooth and poetic as the masters'. They make the exercise approachable and possible, as human as imperfect, so to speak. 
TABLE 5

PHASE OF PRACTICE (BASED ON THE SAME POEM)

\begin{tabular}{|c|c|c|}
\hline exercises & & \\
\hline 1. & Choosing and matching & $\begin{array}{l}\text { Line 1: } \\
\text { a) Qin's bright moon and Han's great pass, not change much } \\
\text { b) The moon shines as in Qin and pass stands as in Han } \\
\text { Line 2: } \\
\text { a) long marched our guardsmen who died protecting this land } \\
\text { b) Our guardsmen's heroic deeds deeply our heart touch }\end{array}$ \\
\hline 2. & Which one is acceptable to you? & $\begin{array}{l}\text { a) Over the old route, shines the same bright crest } \\
\text { b) Moon's as gentle, pass as solemn, as years past }\end{array}$ \\
\hline 3. & $\begin{array}{l}\text { Follow aabb or abab, using one } \\
\text { word }\end{array}$ & $\begin{array}{l}\text { The ever-new moon shines on the aged } \\
\text { Where are our great guardsmen, myself I ask. } \\
\text { Recalling heroic General Li who surely } \\
\text { Against Nomads who dare not to invade this land. }\end{array}$ \\
\hline 4. & $\begin{array}{l}\text { Choose one word to complete } \\
\text { each balanced Structure }\end{array}$ & $\begin{array}{l}\text { Is it the same moon and the ___ pass as we saw? } \\
\text { (similar/old/well-known) } \\
\text { How we miss army-men, but can't___ them any more. (hear/see/talk } \\
\text { to) }\end{array}$ \\
\hline 5. & $\begin{array}{l}\text { Iambus: } \frown / \text { or Trochee: } / \frown \text {. } \\
\text { Analyze the following lines. }\end{array}$ & $\begin{array}{l}\text { The moon is bright, the pass is strong, as yore, } \\
\text { The army-men fought, none back to home any more. } \\
\text { We miss commander Li, who guard and fight, } \\
\text { The Nomads dare not come any more in sight }\end{array}$ \\
\hline 6. & $\begin{array}{l}\text { Decide on the words forming } \\
\text { alliteration or assonance }\end{array}$ & $\begin{array}{l}\text { My friends has left the west where the Yellow crane towers (line from } \\
\text { poem by Li Bai) } \\
\text { The setting sun seems so sublime (line from poem by Li Shangyin) } \\
\text { Perhaps the lovely Zhao Feiyan in her fresh make-up and new fashion dress } \\
\text { (line from poem by Li Bai) } \\
\text { (translators: Xu Yuanchong, Tang Zidong, Shen Zhanchun) }\end{array}$ \\
\hline
\end{tabular}

\section{Summary}

Table 5 shows the content of exercise and process of practice, which are aimed to give general ideas of TACP, with both the process and product as the focus. It is justified by more than one version of translation which facilitates their interpretation and performance, and language learning as a whole. The characteristics of each item of practice are explained in the follow-up reading, to consolidate the concept form in the practice phase.

\section{Follow-up reading}

Follow-up reading provides some background information about the exercises already done and rationale of the practice. It describes and compares features of poetry, introduces techniques, trends, concepts and principles. The short-text reading is intended to reinforce class activities and allow a period of quiet reading and self reflection. The reading takes into account de-contextualization of the training and provides language reference to compensate the lacking of TACP. The training of a translator resembles that of a language user. Cong (2007) sees a competent translator as a person possessing overall knowledge, specialized techniques, genre awareness, and theories related to the genre translation. Wu (1998) holds that the training of a C-E translator requires the categorization of the target knowledge stored for use and a lot of comparative studies. Given that productive skill is like that of translation and emerges through cultivation, classroom training should in every way facilitate that cultivation.

The reading is made up of reviews, translation techniques and theories, as well as translations by different people.

TABLE 6

VIEWS/INTRODUCTION/DEFINITION

\begin{tabular}{|l|l|}
\hline $\begin{array}{l}\text { format of } \\
\text { classic Chinese } \\
\text { poetry }\end{array}$ & $\begin{array}{l}\text { Overall, classical Chinese poems are strict in format, with same-character lines. There are } \\
\text { five-character-line and seven-character-line poetry. The rhyme schemes are more or less regular. } \\
\text { Rhyme and symmetrical expressions are important elements to produce harmonious and musical } \\
\text { effects. Another distinctive feature is ... }\end{array}$ \\
\hline alliteration & $\begin{array}{l}\text { The repetition of the same sound at the beginning of consecutive words has a long history in } \\
\text { European languages. It is used both in verse and prose, as in ... }\end{array}$ \\
\hline foot & $\begin{array}{l}\text { 在汉语中, 诗歌的节奏以此为单位, 通过平人变化表现音韵和谐。英诗也是如此, 不过它 } \\
\text { 的单位不是字, 而是“音步”(foot), 即一定数目的强弱音以一定方式的组合。...... }\end{array}$ \\
\hline
\end{tabular}

\section{Summary}

Table 6 shows fragments of extract reading, directly corresponding to practice activities. Each one is similar to the teacher's oral presentation prior to a particular round of practice. An extract like these rationalizes the learners' activity and mends their understanding gap. With this directory a learner can improve her/his performance at home, gaining confidence. Reading extract can also be a starting-point of a mini research, a result of further reading and thinking, with a few lead-in questions like "What are the syntactic patterns of a five-character or seven-character line of classic Chinese poetry?" "Is there such phenomenon as alliteration in Chinese poetry?" "What are the rhythmic patterns of classic Chinese poetry?" 
TABLE 7

TRANSLATION TECHNIQUES, REVIEWS

\begin{tabular}{|l|l|}
\hline Proper nouns & $\begin{array}{l}\text { 1) 原诗的专有名词被英译为对等的专有名词, 例如: 姑苏城外寒山寺: outside the Suzhou wall, from } \\
\text { Hanshan Temple's bell (poem by Zhang Ji; translator: Cai Tinggan) ....... } \\
\text { 原诗的专有名词被英译为普通名词, 例如: ...... }\end{array}$ \\
\hline $\begin{array}{l}\text { The illocutionary } \\
\text { level }\end{array}$ & $\begin{array}{l}\text { When translators have made up their mind where to place the source text in the culture of the target } \\
\text { language and literature, they set about solving the problems, by proceeding to identify ... }\end{array}$ \\
\hline $\begin{array}{l}\text { Grammar and } \\
\text { presentation }\end{array}$ & $\begin{array}{l}\text { 所谓文言超脱语法、文法的自由, 究竟可以到什么程度, 我们看一个例子, 苏东坡的一句诗: 潮随 } \\
\text { 暗浪雪山倾，我们也可以以另一种方式读这句诗: 倾山雪浪暗随潮, 语法没什么不自然的地方, 而 } \\
\text { 英语这样做完全不可能。...... }\end{array}$ \\
\hline
\end{tabular}

\section{Summary}

This kind of reading widens the learners vision to literature translation in comparative studies, and in a sense is the extension of class activities, based on a written presentation. In terms of TACP the teacher has only limited ideas and resources. By borrowing other people's idea the teacher can enrich the class practice and invent tasks that incite reflection and solution, e.g. by inviting learners to see how proper nouns are translated in other cases, or whether nouns/verbs/adjectives are made into the same part of speech. For target language reading the major points of the passage may be given, in order that the learners get the major theoretical points after reading. In the case of grammar discussion may be held about grammatical characteristics of the English and Chinese poetry, and about how it affects translation.

\section{DISCUSSION AND CONCLUSION}

Literature translation in general and poetry translation in particular, cultivate an awareness of comparative linguistics in the learners. TACP allows structural analyses and syntactic study in many aspects, and these analyses and study need not just specialists' involvement, but also participation of ordinary L2 learners, and need to become approachable through language learning activities. This will imply that translation theories get a bit away from the bookish discussions and concretize themselves into classroom activities which are not very awesome or challenging, and which incorporate with L2 acquisition for daily pursuit and reflection. That being said, it has to be admitted that learning translation is different from regular skill development, where learners immerse themselves, and become as efficient as they forget their mother tongue for a while. In doing translation, particularly C-E translation, learners no longer have the context to immerse themselves; they become "dry" and are learning without much language reference and contextual clues to follow. Receptive skills such as reading and listening represent a typical "bottom-up" trend of learning, in which students have plenty of room to develop themselves until their competence is acquired. They climb a pyramid all the time. Productive skills such as speaking and translation present a picture of a reverse pyramid, a process which requires a certain degree of competence to take up a project. Such a factor also makes the teaching of one such skill very challenging, a factor that prevent many language teachers from venturing on a teaching program of TACP.

Although it is particularly hard for a teacher to come up with effective methods to make the learners competent translators, any seemingly small, insignificant techniques may do them good and any piece of reading that bears the teacher's/researcher's learning experience may prove valuable in class, as long as these techniques and readings are approachable and workable, and able to elicit their participating enthusiasm and interest. In teaching productive skills, the environment to make language acquisition to happen and the teacher's will to make it happen earlier are both essential. This is also true with the learning of TACP.

\section{REFERENCES}

[1] Cong, Z. H. (2007). A Theoretical Study of the Classical Chinese Poetry in English Translation. Beijing: National Defense Industry Press.

[2] Hall, G. (2005). Literature in Language Education. Palgrave Macmillan.

[3] Huang, G.W. (2006). Linguistic Exploration in Translation Studies - Analyses of English Translation of Ancient Chinese Poems and Lyrics. Shanghai: Shanghai Foreign Language Education Press.

[4] Hatim, B. \& I. Mason. (2005). Discourse and the Translator. Beijing: Foreign Language Teaching and Research Press.

[5] Kurn, B. (2009). Benefits of Reading Literature. Yahoo! Contributor Network.

[6] Lefevere, A. (2011). Translating Literature: Practice and Theory in a Comparative Literature Context, New York: The Modern Language Association of America.

[7] Littlewood, W. T. (2006). Literature in the School Foreign-Language Course in Literature and Language Teaching, ed. by C. J. Brumfit \& R. A. Carter. Shanghai: Shanghai Foreign Language Education Press.

[8] Landers, C. E. (2008). Literary Translation: A practical Guide. Shanghai: Shanghai Foreign Language Education Press.

[9] Quah, C.K. (2008). Translation and Technology. Shanghai: Shanghai Foreign Language Education Press.

[10] Tian, H. F. (2013). Learning to Interpret and Translate Classical Chinese Poetry. Theory and Practice in Language Studies, 2013, 9: P. 22.

[11] Wu, X.M. (1998). Aspects of Literature Translation. Beijing: Foreign Language Studies Press.

[12] Xu, Y.C., Tang, Z.D. \& Shen, Z.C. (2004). 100 Tang and Song Quatrain Masterpieces by Great Poets. Changchun: Jilin Culture and History Press.

[13] Xu, Y.C. (2010). On Chinese Verse in English Rhyme. From the Book of Poetry to the Romance of the Western Bower. Beijing: 
Beijing University press.

[14] Zhang, F. (2002). The Integrity of Meaning and Form in Ancient Poetry Translation. Chengdu: Hua Wei Press.

[15] Zhuo, Z. Y. (2011). A Theoretical Outline of Chinese Verse Translation. Hangzhou: Zhejiang University Press.

Huifang Tian was born in Tang Shan, Hebei Province, Mar. 1966. He received his Bachelor Degree of Art from the Department of Foreign Languages, Hebei Normal University, Hebei Province, Sept. 1989.

$\mathrm{He}$ is Associate Professor, and currently teaching English at the School of Foreign Languages, China University of Petroleum, Beijing. His research interests include foreign language teaching and education, and English for Specific Purposes, author of several articles on language teaching and research of well-acknowledged journals. 